\title{
Prevalence of Leptospirosis Antibodies in the European Hare (Lepus europaeus Pall.) in the District of Břeclav
}

\author{
F. TREML ${ }^{1}$, J. PIKULA $^{2}$, Z. HOLEŠOVSKÁ ${ }^{2}$ \\ ${ }^{1}$ Department of infectious diseases and epizootiology \\ ${ }^{2}$ Department of Veterinary Ecology and Environmental Protection \\ Veterinary and Pharmaceutical University Brno, Czech Republic
}

Received October 24, 2002

Accepted September 22, 2003

\begin{abstract}
Treml F., J. Pikula, Z. Holešovská: Prevalence of Leptospirosis Antibodies in the European Hare (Lepus Europaeus Pall.) in the District of Břeclav. Acta Vet. Brno 2003, 72: 377-381.

Between 1999 to 2001 a total of 604 blood sera from the European hare (Lepus europaeus Pall.) from the district of Břeclav were examined for the presence of anti-leptospiral antibodies. Positive reactions were found in 96 cases (i.e. 15.89\%). Antibodies were found every year of the study. The incidence, however, differed $(13.15 \%, 10.28 \%, 28.85 \%)$. The examined positive sera reacted only with L. grippotyphosa $(93.75 \%)$ and L. grippotyphosa /L. bulgarica (6.25\%). Most reactions were at the titre of 100 (41cases of reactions against L. grippotyphosa and L. bulgarica; 40.18\%), whereas the least number of reactions was found at the titre of 3200 (4 cases; $3.91 \%$ ).

It was found that the European hare is susceptible to the infection by leptospires and the etiological structure of leptospiral antibodies corresponds to that in other small mammals. Blood sera of the European hare thus could be used for purposes of monitoring the leptospiral foci in the nature. The European hare plays only a limited role in direct infection of humans or persistence of the natural focus of leptospirosis. It is, however, necessary to be careful when handling game animals.

Leptospirosis, antibodies, L. grippotyphosa, European hare
\end{abstract}

The European hare (Lepus europaeus Pall.) is an important game animal in the Czech Republic where it is distributed throughout more than $80 \%$ of hunting grounds. It is important both from economic and hunting aspects. The economic importance depends both on its population density, venison production and export entity.

Recently, there has been growing attention paid to control of the health status of the European hare in the hunting grounds. Among free-living animals, this species acts as a very sensitive bioindicator reacting to all adverse environmental influences. Infections and parasitic diseases belong, no doubt, to important biotic factors influencing the hare populations. The epizootiological importance of the European hare lies mainly in the fact that it is a game animal inhabiting limited areas, home ranges, thus increasing the risk of outbreak of a number of infections and parasitic diseases. Apart from common diseases such as staphylococcosis, hemorrhagic septicaemia, pseudotuberculosis and brucellosis, the European hare may host zoonotic agents including tularaemia, listeriosis, toxoplasmosis and leptospirosis.

As a part of monitoring of the occurrence of tularaemia in the European hare in South Moravia, we collected blood sera of specimens shot and examined them for the presence of antibodies against leptospires.

\section{Materials and Methods}

During three years (1999 to 2001) a total of 604 blood sera of the European hare specimens shot in various hunting grounds of the Břeclav district were obtained and examined. In 1999, 2000 and 2001 blood sera amounted to 228, 175 and 201, respectively. Blood was collected by heart puncture of specimens shot during autumn hunting events. It was then centrifuged and the serum obtained used in the reaction of micro-agglutination lysis with 12 
strains of leptospires according to the standard methods (Sebek 1979) using following serotypes of leptospires at the basic titre of 100: 1. L. grippotyphosa-P125; 2. L. icterohaemorrhagiae-Fryšava; 3. L. sejroe - M84; 4 . L. canicola-C7; 5. L. bratislava - Jež Bratislava; 6. L. pomona - Šimon; 7. L. arboreae - M7; 8. L sorex jalna Sorex Jalna; 9. L. bulgarica - Nikolaevo; 10. L. bataviae - Moldava; 11. L. tarassovi - S42; 12. L. pyrogenes Salinem. Sera reacting at the basic titre of 100 were further examined with the respective strain up to the highest titre.

\section{Results}

Antibodies against leptospires of various serotypes in the European hare specimens were found in every year of the study. Their incidence, however, varied between 1999 and 2001 $(13.15 \%, 10.28 \%, 28.85 \%$, respectively). A total of 96 positive reactions (i.e., $15.89 \%)$ were found. The highest proportion of positive reactions was found in 2001 (58 cases), while in 1999 and 2000 it was considerably lower (30 and 18 cases, respectively; see Fig. 1). Antibodies against only two serotypes were found (L. grippotyphosa and L. bulgarica.). A total of 90 examined sera $(93.75 \%)$ reacted with one serotype, i.e., L. grippotyphosa. The remaining 6 cases $(6.25 \%)$ reacted with both leptospiral serotypes, i.e., L. grippotyphosa and $L$. bulgarica. Antibodies against the $L$. bulgarica serotype were always found as coagglutinations together with the anti-L. grippotyphosa antibodies. No other positive reactions with other leptospiral serotypes were found (see Fig. 2).

Considering the titre, reactions varied from 100 to 3200 . Most reactions against the

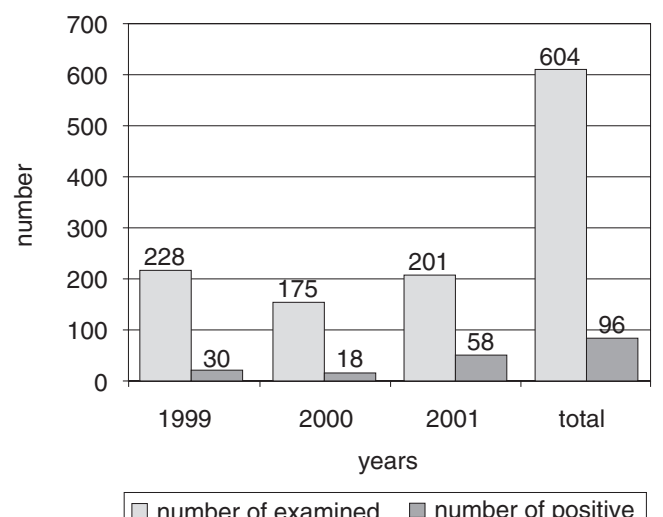

Fig. 1. Results of blood sera examinations for the presence of antibodies against leptospires in the Europeaan hare in 1999-2001

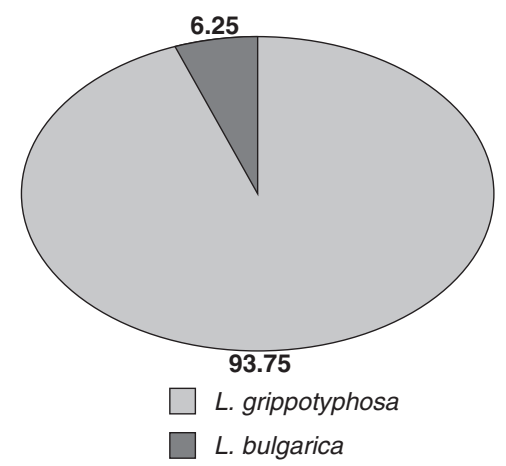

Fig. 2. Serotypes of antibodies found 
serotype of L. grippotyphosa were at the titre of 100 (37 cases; 36.26\%), while least reactions amounted up to the titre of 3200 ( 4 cases; $3.91 \%$ ). Antibodies against L. bulgarica were found only at low titres with concurrent much higher titres against $L$. grippotyphosa (see Fig. 3).

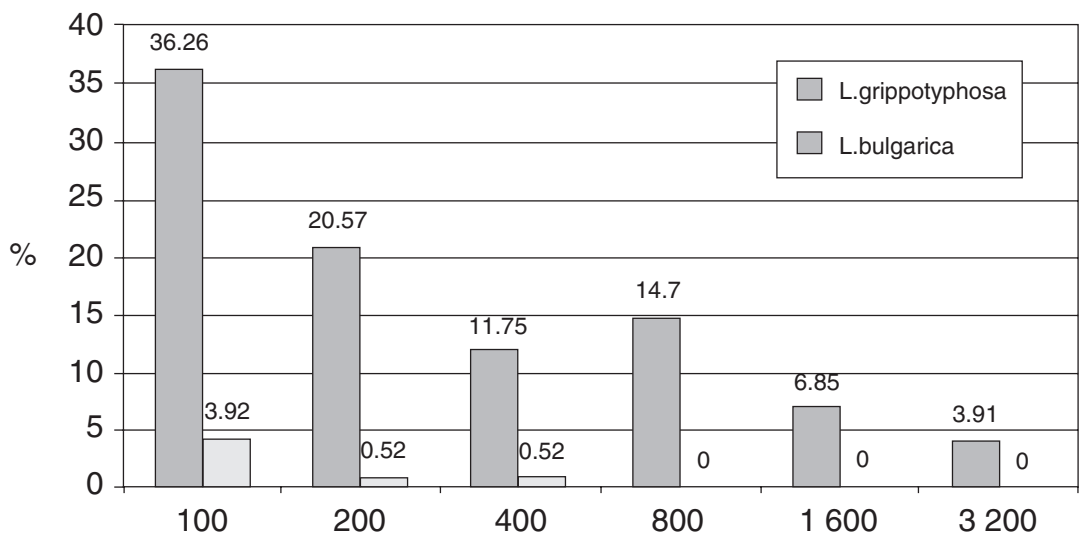

Fig. 3. Titres of antibodies against leptospires found in European hare blood sera

\section{Discussion}

Serology of blood sera of the European hare specimens resulted in finding antibodies against the L. grippotyphosa serotype and occasionally $L$. bulgarica. The seropositivity of examined sera varied around $16 \%$. From the results it is clear that the European hare specimens get into contact with leptospires in their environment. Similar results were previously obtained by Sebek and Vosta (1958) and Vosta (1961) studying antibodies against leptospires in this species in the regions around Tábor and Jihlava, as well as Asmera (1960) in the region of Ostrava, more recently Treml and Nesňalová (1993) and Zitek and Babicka (2000). According to the above-cited papers, the serological positivity of the European hare amounted to $10 \%$, on average. In some areas, however, up to $25 \%$ of specimens were positive, whereas in others the anti-leptospiral antibodies were not found at all. Like in our results, these authors found antibodies against $L$. grippotyphosa to be prevailing. Asmera (1991) confirmed the presence of this serotype of leptospires in the European hare by culture. Similar results were published by some authors in other countries. Zanni et al. (1995) confirmed the presence of antibodies against leptospires in $6.8 \%$ of hares imported from Poland and the Czech Republic. Antibodies against leptospires in hares were, for example, found by Hartman and Broekhuizen (1980) in the Netherlands, Giraudo et al. (1985) in Spain, Borcic et al. (1989) in Croatia, Dedek et al. (1990), Geuchen (1993) and Kwapil (1993) in Germany, Trifunovic et al. (1991) in Serbo-Croatia, and others. The serotypes found by these authors, however, differed from ours. In our opinion, it is due to the difference in the occurrence of natural foci of specific serotypes of leptospires in a given area where the material comes from. Under conditions of the Czech Republic, foci of the L. grippotyphosa serotype clearly prevail. This serotype is often responsible for up to $90 \%$ of positive reactions in animals examined (Sebek and Rosický 1974). The common vole (Microtus arvalis) is the main reservoir animal of this serotype of leptospires in the Czech Republic with a seropositivity of up to $42.5 \%$ (Sebek and Rosický 1974). As this species occurs throughout the territory and biocoenoses of the Czech Republic, we can expect the presence of foci of leptospirosis anywhere. The European 
hare inhabiting more or less the same habitats can thus get into direct or indirect contact with this infectious agent. Reactions of the L. bulgarica serotype can only be considered as coagglutinations with $L$. grippotyphosa. This is also evidenced by relatively low titres of this serotype. This has to be considered when diagnosing diseases caused by leptospires in order not to misinterpret the results. Titres of antibodies against the L. grippotyphosa serotype also do not reach high levels so we can speculate that the European hare serves only as a chance reservoir of leptospires and has a limited importance for the maintenance of the foci. It is, nevertheless, necessary to be careful when handling the game animals shot, in particular, when emptying the urinary bladder to prevent direct contact of urine and skin injuries and abrasions because it is in urine that the leptospires are passed to the external environment.

\section{Výskyt protilátek proti leptospirám u zajíce polního (Lepus europaeus Pall.)}

V letech 1999-2001 bylo vyšetřeno 604 krevních sér zajíce polního (Lepus europaeus Pall.) z břeclavského okresu. Pozitivní reakce byly prokázány v 96 případech $(15,89 \%)$. Protilátky proti leptospirám byly zjištovány $\mathrm{v}$ každém sledovaném roce, ale $\mathrm{s}$ různou incidencí pozitivity $(13,15 \%, 10,28 \%, 28,85 \%)$. Vyšetřovaná pozitivní séra reagovala pouze s leptospirami L. grippotyphosa $(93,75 \%)$ a L. grippotyphosa/L. bulgarica $(6,25 \%)$. Vyšetřovaná séra reagovala nejčastěji $\mathrm{v}$ titru 100 a to $\mathrm{v} 41$ př́ipadech reakcí proti $L$. grippotyphosa a L. bulgarica $(40,18 \%)$, zatímco nejméně reakcí bylo prokazováno v titru 3200 a to 4 případy $(3,91 \%)$.

Bylo prokázáno, že zajíc polní je vnímavý k infekci leptospirami, přičemž zjištovaná etiologická struktura leptospirových protilátek koresponduje s výskytem protilátek u drobných zemních savců. Krevní séra zaječí zvěře by bylo možno využít v rámci monitoringu ohnisek leptospiróz v prrírodě. Pro přímou infekci člověka a udržování přírodního ohniska má zajíc polní význam pouze omezený, přesto je třeba věnovat zvýšenou pozornost manipulaci se zvěří.

Acknowledgements

This work was supported by the Grant Agency of the Czech Republic (No. 524/00/1122).

\section{References}

ASMERA, J 1960: Serological confirmation of the presence of L. grippotyphosa in the European hare (Lepus europaeus Pall.) (In Czech) Čs epidemiol mikrobiol imunol 9: 501-504

ASMERA, J 1991: Problems of leptospiroses in north Moravia. (In Czech). Státní pedagogické nakladatelství, Praha, $114 \mathrm{p}$.

BORCIC, B, RAOS, B, SEBEK, Z, KRANCELIC, D, ELDAN, JA, FILIPOVIC, V 1989: Leptospiral antibodies in large game animals in northern Croatia. (In Serbo-Croatian) Veterinarski arhiv, 59: 117-123

DEDEK, J, LOPELMANN, H, KOKLES, R 1990: Results of serological survey for selected infections among field hares (Lepus europaeus) in the German Democratic Republic. (In German). In: Verhandlungsbericht des 32. Internationalen Symposiums über die Erkrankungen der Zoo- und Wildtiere, 23. - 27. Mai 1990, Eskilstuna, pp. 199-204

GEUCHEN, P 1993: Hygienic status of shot field hares from a game reserve in the southern Lower Rhine area of Germany. Inaugural - Dissertation, Hanover (Germany), 106 pp. (In German)

GIRAUDO, JA, DAURIA, PG, De La CRUZ, JP, BAGNAT, E 1985: Anti-leptospira and anti-brucella agglutinins in hares (Lepus europaeus) from Rio Cuarto Department, Province of Cordoba. Rev Argent Microbiol 17: 221223 (In Spanish)

HARTMAN, EG., BROEKHUIZEN, S. 1980: Antibodies to Leptospira in European hares (Lepus europaeus Pallas) in the Netherlands. Zbl Veterinärmed [B] 27: 640-649 (In German)

KWAPIL, S 1993: Bacteriological, virological and parasitological studies on brown hares. Inaugural Dissertation, Hannover (Germany), 142 p. (In German)

SEBEK, Z 1979: Standard methods of laboratory diagnostics of leptospiroses. Acta Hyg Epidemiol Microbiol, príloha 2, 18 p. (In Czech)

SEBEK, Z, VOSTA, J 1958: Results of serological examinations of hares for leptospires. Čs Epidemiol Mikrobiol Imunol 7: 336-339 (In Czech) 
SEBEK, Z, ROSICKY, B 1974: On the occurrence, characteristics and structure of the foci of leptospirosis in Czechoslovakia. Čs Epidemiol Mikrobiol Imunol 23: 10-21 (In Czech)

TREML, F, NESŃALOVÁ, E 1993: Leptospiral antibodies in the serum of game animals. Vet Med - Czech 38: 123-127 (In Czech)

TRIFUNOVIC, Z, NESIC, D, ROMANIC, S, PALIC, D 1991: A study of leptospirosis in hares (Lepus europaeus Pallas) in two regions of Serbia. Acta Vet Beograd 14: 41-46

VOSTA, J 1961: Leptospiral foci in the region around Tábor. Čs Parazitol 8: 403-414 (In Czech)

ZANNI, ML, POGLAYEN, G, MARZADORI, F, BENASSI, MC, CAPUCCI, L, CARPENE, E, MAGNINO, S,

TAGLIAUBE, A, SERRA, R, VENTURI, L, BARTOLUCCI, M, GALUPPI, R, LAVAZZA, A 1995: Monitoring the health of hares (Lepus europaeus Pallas) in Ravenna province. Selezione - Veterinaria 36: 1-26 (In Italian)

ZITEK, K, BABICKA, C 2000: Serological prevalence of leptospirosis in game animals in the Czech Republic. Veterinářství 50: 359-357 (In Czech) 